\title{
Pemrosesan Data Buta Aksara Berbasis WebGIS
}

\author{
Fitri Imansyah ${ }^{\# 1}$

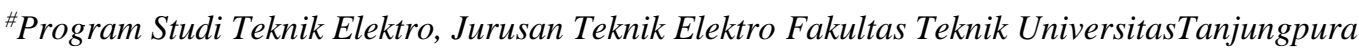 \\ JL. Prof. Dr. H. Hadari Nawawi, Kota Pontianak, Kalimantan Barat \\ ${ }^{1}$ fitri.imansyah@ee.untan.ac.id
}

\begin{abstract}
Abstrak-Penelitian ini berupa aplikasi Sistem Informasi Geografis (SIG) tentang persebaran data buta aksara berbasis web dengan wilayah penelitian di Kabupaten Sambas diharapkan dapat member petunjuk dan kemudahan bagi para pengguna untuk memperoleh informasi mengenai persebaran data buta aksara berbasis web dengan cepat, akurat, dan dapat diakses oleh siapa saja, dimana saja, kapan saja tanpa mengenal jarak dan waktu. Webgis digunakan karena dalam penyampaian dan tampilan system informasi geografis lebih informatif serta mempresentasikan kondisi sebenarnya. Aplikasi ini dibuat menggunakan struktur website HTML, bahasa pemrograman (javascript dan PHP), MySQL sebagai pembuat database, serta menggunakan peta dasar Google Map. Hasil penelitian ini berupa aplikasi SIG persebaran data buta aksara berbasis web menggunakan google map API yang merupakan aplikasi open source terintegrasi dalam website. Hasil dari pengujian menunjukkan bahwa SIG yang dibangun telah memenuhi kebutuhan sistem dan permasalahan.
\end{abstract}

Kata kunci-Data Buta Aksara, Google Map API, WebGIS.

\section{Pendahuluan}

Penelitian ini merupakan kelanjutan dari penelitian sebelumnya yang berjudul Pemetaan Sebaran Data Buta Aksara Berbasis Sistem Informasi Geografis Dan Data Base Engine. Hasil dari penelitian tersebut berupa GIS yang bersifat offline [4]. Untuk itu dibuat kelanjutan dari penelitian tersebut berbasis online (WebGIS). Konsep dasar Web GIS adalah sistem yang dirancang untuk bekerja dengan data yang tergeoreferensi secara spasial. GIS memiliki kemampuan untuk melakukan pengolahan data dan melakukan operasi-operasi tertentu dengan menampilkan dan menganalisa data. Aplikasi GIS saat ini tumbuh tidak hanya secara jumlah aplikasi namun juga bertambah dari jenis keragaman aplikasinya [2, 3,7].

Saat ini telah dikenal istilah-istilah Desktop GIS, WebGIS, dan mobile GIS yang merupakan wujud perkembangan teknologi Sistem Informasi Geografis, untuk mengakomodir kebutuhan solusi atas berbagai permasalahan yang hanya dapat dijawab dengan teknologi GIS ini.

GIS merupakan sistem yang dirancang untuk bekerja dengan data yang tereferensi secara spasial atau koordinatkoordinat geografi.
WebGIS merupakan aplikasi GIS yang dapat diakses secara online melalui perangkat komputer maupun mobile phone. Pada konfigurasi WebGIS ada server yang berfungsi sebagai Map Server yang bertugas memproses permintaan informasi dari user dan kemudian mengirimkannya ke server. Dalam hal ini pengguna/user tidak perlu mempunyai software GIS, hanya menggunakan browser seperti Internet Explorer, Mozilla Firefox, atau Google Chrome untuk mengakses informasi GIS yang ada di server sesuai dengan kebutuhan.

GIS memiliki kemampuan untuk melakukan pengolahan data dan melakukan operasi-operasi tertentu dengan menampilkan dan menganalisa data spatial dan tabular menjadi sebuah informasi [13]. Tujuan dari WebGIS buta aksara ini adalah untuk memudahkan pencarian data dan informasi tentang sebaran buta aksara di Provinsi Kalimantan Barat. Dengan adanya WebGIS ini informasi dapat tersusun dengan baik, akurat, mudah dibaca, dan mudah dimengerti oleh orang awam sekalipun.

Secara umum penyusunan dan pemrosesan data buta aksara di Kalimantan Barat berbasis WebGIS bertujuan:

1. Memberikan gambaran situasi dan kondisi existing keaksaraan di Provinsi Kalimantan Barat sehingga instansi yang terkait dapat mengambil tindakan lebih lanjut untuk menekan buta aksara tersebut.

2. Mempermudah akses pemrosesan data buta aksara secara real time pada seluruh kabupaten yang ada di Kalimantan Barat dengan media Web.

3. Mempermudah dalam pemutakhiran data buta aksara yang ada di Kalimantan Barat.

Sasaran yang diharapkan dari kajian ini adalah:

1. Bagi pemerintah Provinsi Kalimantan Barat diharapkan hasil studi ini dapat merupakan masukan di dalam mengambil tindakan untuk menekan angka kebutaaksaraan masyarakat yang ada di Kalimantan Barat dengan memahami sebaran keaksaraan dan kondisi eksisting masyarakat buta aksara.

2. Bagi masyarakat umum dapat mengakses WebGIS buta aksara yang dihubungkan dengan server dengan menyorot ke SKPD Dinas Pendidikan dan Kebudayaan.

3. Terciptanya suatu sistem informasi buta aksara terpusat 
berbasis WebGIS sehingga meminimalisir ketidakakuratan data buta aksara.

Dampak yang diperkirakan dapat dirasakan dari studi ini adalah kemudahan dalam mengakses history data untuk aksara yang ada di Kalimantan Barat, sehingga dapat membantu pihak terkait yang dalam hal ini adalah Dinas Pendidikan dan Kebudayaan Provinsi Kalimantan Barat untuk mengambil kebijakan dalam upaya menekan angka buta aksara masyarakat. Dengan tampilan data yang up to date dan real time serta dipadukan dengan pemetaannya, akan lebih jelas terlihat kondisi eksisting keadaan sebaran buta aksara yang ada di Kalimantan Barat.

WebGIS yang akan dikembangkan dapat menjadi dasar/basis pengembangan Sistem Informasi Geografis Pemantauan Sebaran Keaksaraan berbasis Web yang memungkinkan untuk dimanfaatkan bagi Dinas Pendidikan dan Kebudayaan Provinsi Kalimantan Barat dan dapat diintegrasikan ke dalam Website Provinsi Kalimantan Barat. Persyaratan umum pemetaan sebaran keaksaraan yang dikembangkan adalah harus :

1) Fungsional: yaitu web yang buat dapat bermanfaat dalam memberikan informasi sebaran keaksaraan, yang berkaitan dengan kegiatan-kegiatan untuk menekan angka masyarakat buta aksara.

2) Sustainable: artinya web yang dibuat mampu untuk terus berkembang sesuai dengan kebutuhan aktivitas pendidikan.

3) Mudah dan user friendly: web yang dibuat mampu harus mudah dimengerti dan dioperasionalkan serta mudah di update khususnya oleh calon pengguna.

4) Handal: web ini juga harus memuat kemampuankemampuan atau fungsi-fungsi informasi yang dibutuhkan.

Layak dari segi biaya, artinya dalam pengembangannya harus disesuaikan dengan kemampuan daerah dalam penyediaan hardware dan software pendukung sistem, termasuk juga perawatan sistem $[5,6,8]$.

Untuk pengembangan WebGIS ini digunakan software sebagai berikut:

- Sistem Operasi Windows 7 Home Premium

- Notepad++

- Database MySQL

- AppServ

- ArcGIS 10.1

- Google Maps API

Pada dasarnya banyak software yang dapat digunakan untuk membangun aplikasi WebGIS baik yang berbayar maupun yang gratis. Software WebGIS berbayar: ESRI ArcGIS Server, Geo Media Web Map, Map Info Map Xtreme dan lain-lain. Sedangkan untuk Open source: $S G e o$ Live, SAGA GIS, MS4W (MapServer For Windows), PostgreSQL, MapGuide Open Source, ALOV, GeoServer, MapBender, Open Layer dan lain-lain [9,10,1214].

Perkembangan kearah masa depan, penggunaan aplikasi WebGIS akan semakin luas dan makin banyak. Adapun beberapa keuntungan dari penggunaan aplikasi WebGIS , sebagai berikut imi:
1. Dapat menjangkau pengguna yang luas bahkan seluruh dunia, dengan biaya yang cukup murah.

2. Pengguna tidak perlu perangkat lunak khusus, cukup menggunakan internet browser seperti Internet Explorer, Mozilla Firefox, Google Chrome dan lain sebagainya.

3. Bisa menyajikan peta interaktif seperti halnya menggunakan perangkat lunak GIS desktop.

4. Tidak tergantung dari sistem operasi sehingga bisa dioperasikan pada semua komputer dengan berbagai sistem operasi.

5. Tidak memerlukan software dan tool khusus dalam pengoperasiannya karena pada dasarnya yang diperlukan hanyalah browser yang bisa didapatkan secara cuma-cuma.

6. Memiliki kemampuan operasi yang setara dengan user interface yang dikembangkan dengan tidak berbasis web.

GIS berbasis web telah membantu dengan sangat mudah untuk berbagi data spasial melalui World Wide Web dan dapat diakses oleh setiap pengguna di setiap sudut dunia tanpa memiliki software GIS khusus yang dimuat pada mesinnya. Web GIS memiliki potensi untuk merevolusi cara di mana GIS dikembangkan, diakses dan digunakan di seluruh dunia. Gambaran umum WebGIS Buta Aksara yang akan dibangun, digambarkan pada Arsitektur Sistem, seperti tergambar di bawah ini:

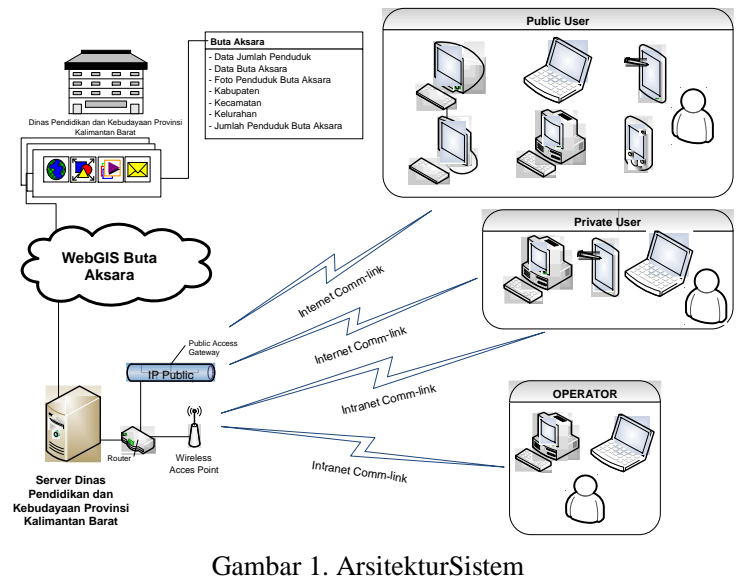

Penjelasan Arsitektur Sistem:

1. Sistem berbasis web dikelola pada Server Dinas Pendidikan dan Kebudayaan Provinsi Kalimantan Barat.

2. Sistem merupakan aplikasi WebGIS yang mengkorelasikan data spasial dan manajemen data tabular. Data spasial berupa Administrasi Kabupaten, Kecamatan dan Kelurahan.

3. Sistem dibangun dalam dua Communication-Link yaitu Internet dan Intranet.

4. User aktif pada sistem terdiri dari:

a) Operator: Pengguna yang bertugas melakukan manajemen data. Operator berkomunikasi dengan 
sistem melalui jaringan intranet. Operator memiliki previleges hak akses) khusus untuk manajemen data, serta setiap aktivitas operator dilakukan pencatatan pada log systems.

b) Private User: Pengguna masing-masing kabupaten yang diberikan hak akses untuk memanajemen data buta aksara. Private User berkomunikasi dengan sistem melalui jaringan internet dan intranet. Setiap user akan diberikan privilege khusus, serta setiap aktivitas operator dilakukan pencatatan pada log systems.

c) Public User: Pengguna umum yang dapat kapan saja melakukan akses informasi pada sistem. Public User tidak diberikan privilege khusus, karena tidak diperkenankan melakukan manajemen data.

5. Sistem dibangun dengan security sistem multilayer, menerapkan high level encrypt dan special privilege bagi Operator dan Private User.

\section{METODE PENELITIAN}

Metode penelitian yang akan dilakukan adalah:

1) Studi literatur: Studi literatur dilakukan guna memahami materi-materi yang berkaitan dari beberapa literatur.

2) Pengumpulan Data: Pengumpulan data dilakukan dengan mengambil data dari Dinas Pendidikan dan Kebudayaan Provinsi Kalimantan Barat (data sekunder) dan melakukan observasi lapangan (data primer) berdasarkan kegiatan sebelumnya.

3) Perancangan konseptual: perancangan konseptual dari sistem yang akan dibangun. Berupa perancangan Data Flow Diagram (DFD) sistem dan menentukan metode pemetaan keaksaraan.

4) Perancangan prototype sistem: Merupakan implementasi langkah ketiga ke dalam bentuk aplikasi.

5) Pengujian dan validasi sistem: Pengujian dilakukan pada sistem untuk memeriksa apakah sistem dapat berjalan dengan benar sesuai dengan yang diharapkan oleh pengguna. Pengujian ini melibatkan data real yang didapat dari pengguna tanpa memperhatikan detail internal dari sistem. Kemudian data divalidasi menggunakan pengujian blackbox.

6) Penarikan kesimpulan: Kesimpulan dirumuskan berdasarkan analisis yang telah dilakukan apakah sistem yang dirancang mampu memberikan informasi secara geografis mengenai sebaran keaksaraan yang ada di Provinsi Kalimantan Barat sehingga mudah dipahami untuk mengambil kebijakan dalam upaya menekan angka buta aksara pada masyarakat.

Diagram alir metodologi penelitian dapat dilihat pada gambar berikut.

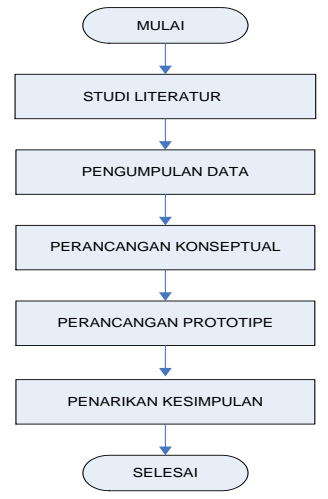

Gambar 2. Diagram alir metodologi penelitian

Dalam melakukan perancangan sistem terdapat tahapan-tahapan yang dilakukan yaitu:

1) Perancangan diagram alir sistem: Tahapan perancangan diagram alir sistem terdiri dari flowchart sistem yang akan dibangun. Diagram alir sistem merupakan diagram yang menggambarkan sistem yang akan dibangun. Data keaksaraan yang didapat dari hasil survey akan diinputkan ke database melalui sistem informasi geografis keaksaraan. Dari data-data tersebut akan dilakukan perhitungan dan akan dianalisis dengan menghubungkan berbagai aspek keterkaitan penunjang pendidikan. Aspek-aspek tersebut meliputi ketersedian sarana dan prasarana di antaranya gedung sekolah, jalan, dan jumlah guru yang ada. Selain itu keaksaraan juga dipengaruhi oleh aspek kebudayaan masyarakat dimana masyarakat tersebut tinggal. Adapun diagram alir sistem yang akan dibangun dapat dilihat pada gambar berikut:

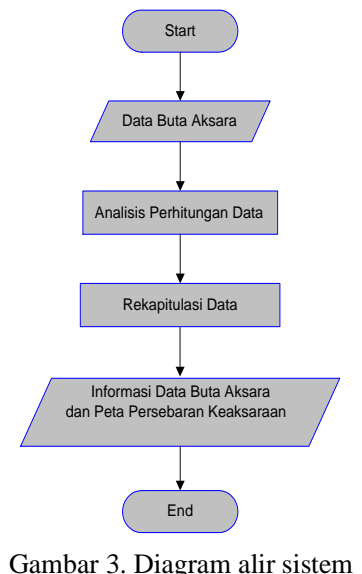

2) Perancangan diagram konteks sistem: Diagram konteks adalah diagram yang memberikan gambaran umum terhadap kegiatan yang berlangsung dalam sistem. Gambar berikut ini menunjukkan diagram konteks dari sistem yang akan dibangun. 


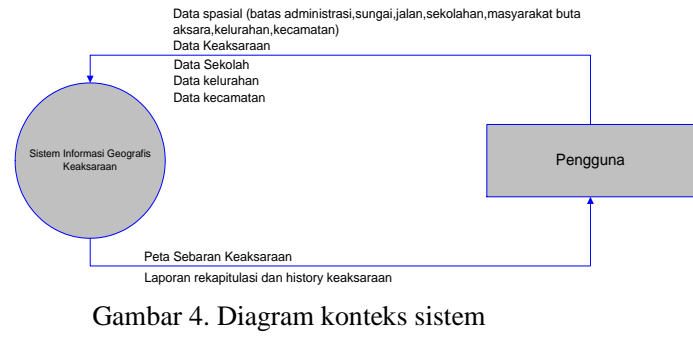

Sistem informasi geografis keaksaraan yang dirancang hanya memiliki beberapa level pengguna. Pengguna yang dimaksud dalam sistem ini adalah Dinas Pendidikan dan Kebudayaan Provinsi Kalimantan Barat, ataupun pihakpihak terkait seperti organisasi kemasyarakatan dan lembaga penelitian yang ingin mendapatkan informasi masalah keaksaraan masyarakat yang dihasilkan oleh sistem ini.

3) Perancangan basis data: Tahapan perancangan basis data terdiri dari perancangan Entity Relationship Diagram (ERD), spesifikasi tabel basis data tabular, spesifikasi tabel basis data spasial, diagram hubungan antar tabel data tabular dan model hubungan data spasial dan data tabular. Model hubungan antara data spasial dan data tabular dalam sistem informasi geografis ini dapat dilihat pada Gambar berikut.

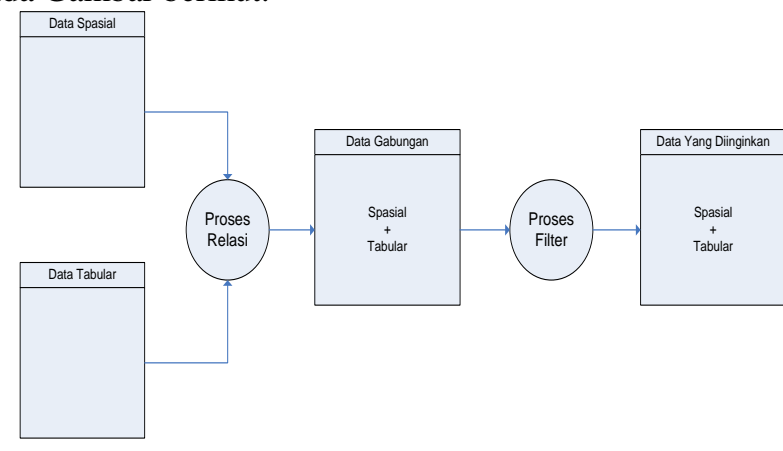

Gambar 5.Model hubungan antara data spasial dan data tabular

Untuk pengembangan WebGIS ini digunakan software sebagai berikut: Sistem Operasi Windows 7 Home Premium, Notepad++, Database MySQL, AppServ, ArcGIS 10.1, Google Maps API. Data spasial dilakukan digitalisasi sendiri. Tabel yang digunakan ada empat, yaitu tbl_kec, tbl_kelurahan, tbl_sekolahan, tbl_keaksraan. Tabel-tabel ini dibuat menggunakan database MySQL. Hubungan antara tabel-tabel data tabular dalam sistem informasi geografis ini dapat dilihat pada gambar berikut.

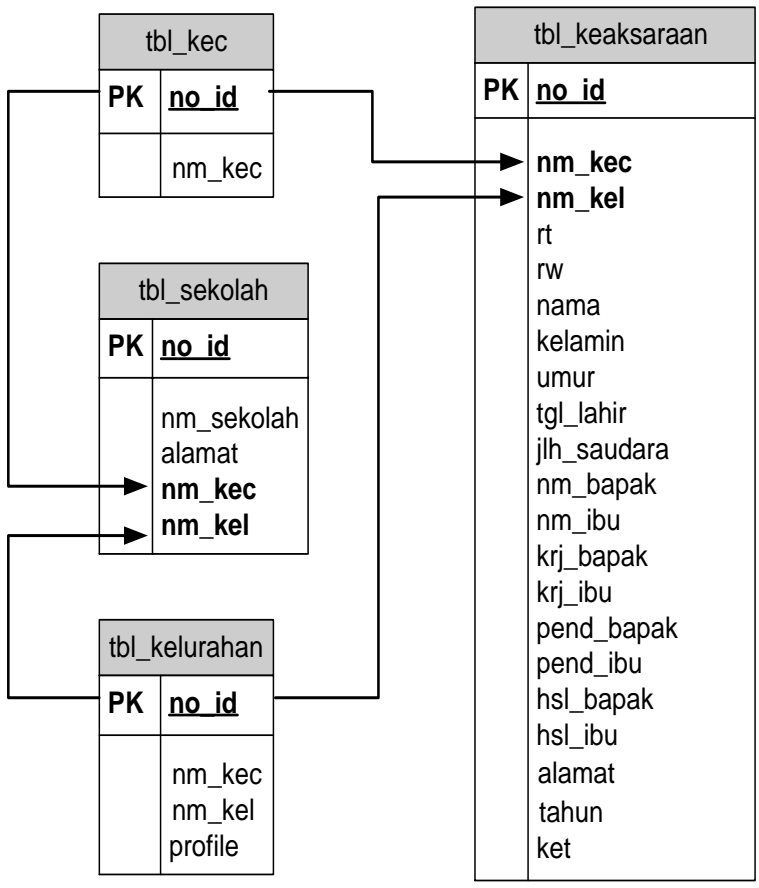

Gambar 6.Diagram hubungan antar tabel data tabular

4) Pemodelan Data: Berikut ini adalah data kegiatan Keaksaraan yang dilakukan oleh PKBM yang ada di Provinsi Kalimantan Barat. Dari pemodelan data yang dilakukan oleh PKBM peneliti mencoba untuk menambahkan beberapa pendukung sehingga dapat meminimalisir terjadinya duplicate data buta aksara. Untuk format data buta aksara by name by address yang peneliti buat sesuai dengan perancangan database. Adapun format tersebut adalah dalam bentuk microsoft office excel. Tampilan data dalam format microsoft office excel dapat dilihat pada tabel berikut.

TABEL I

TAMPILAN Format PENDATAAN BUTA AKSARA

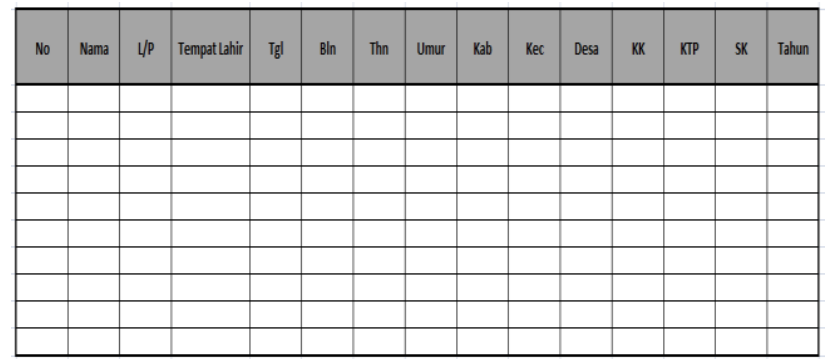

Dari data buta aksara dalam bentuk micrsoft office excel, kemudian akan di upload ke database MySQL oleh tiap-tiap admin kabupaten melalui aplikasi WebGIS Buta Aksara.Setelah data berhasil disimpan, maka secara otomatis data tersebut akan tampil pada tabel buta aksara yang terdapat pada halaman Web, seperti terlihat pada gambar berikut. 


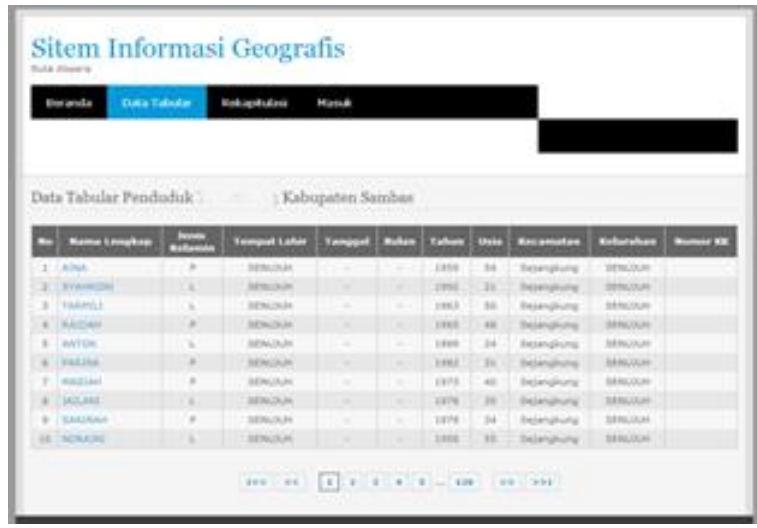

Gambar 7.Tampilan data buta aksara

5) ImplementasiSistem Webgis Buta Aksara: Dari hasil perancangan konseptual dan prototype sistem yang akan di bangun, maka didapatlah sebuah kesimpulan bagaimana model pengolahan dan pemetaan data buta aksara berbasis WebGIS. Dengan adanya aplikasi WebGIS ini diharapkan pemetaan dan pemutakhiran data buta aksara yang ada di Provinsi Kalimantan Barat dapat berjalan secara maksimal sehingga permasalahan akan data buta aksara yang selama ini dirasakan oleh Dinas Pendidikan dan Kebudayaan Provinsi Kaliamantan Barat dapat teratasi. Berikut tampilan utama WebGIS pemetaan data ButaAksara.

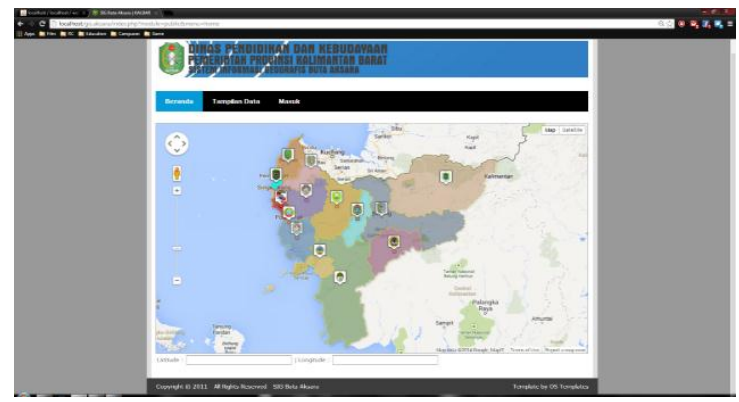

Gambar 8.Tampilan utama WebGIS buta aksara

Pada form utama ini, terdapat beberapa tab menu yang memiliki fungsinya masing-masing. Detail dari fungsi tab menu tersebut dapatdilihat pada tabel 2 .

TABEL III

DAFTAR MENU FORM UTAMA DAN FUNGSINYA

\begin{tabular}{|l|l|}
\hline \multicolumn{1}{|c|}{ Menu } & \multicolumn{1}{c|}{ Fungsi } \\
\hline Beranda & $\begin{array}{l}\text { Menampilkan peta utama berupa sebaran buta } \\
\text { aksara berdasarkan kabupaten }\end{array}$ \\
\hline $\begin{array}{l}\text { Data } \\
\text { Tabular }\end{array}$ & $\begin{array}{l}\text { Menampilkan data buta aksara by name by } \\
\text { address }\end{array}$ \\
\hline Rekapitulasi & $\begin{array}{l}\text { Menampilkan data buta aksara yang telah } \\
\text { direkap oleh admin ataupun operator }\end{array}$ \\
\hline Masuk & Login admin atau operator \\
\hline
\end{tabular}

Pada bagian bawah tab menu terdapat peta batas administrasi Kabupaten yang menerangkan persentase buta aksara melalui warna pada masing-masing batas administrasi kabupaten. Peta yang ditampilkan pada form ini terdiri dari layer-layer yang disusun bertumpuk (overlay layer), dimulai dari layer kabupaten di bagian paling bawah dan layer kecamatan paling atas. Pengguna dapat memilih layer yang ingin diaktifkan dengan memilih popup теnи layer aktif yang berada di sebelah kiri peta. Selain memilih layer, pengguna juga dapat langsung menuju pada kabupaten dan kecamatan yang ingin dilihat datanya dengan memilih nama kabupaten yang diinginkan pada combobox yang terdapat dibagian bawah pengaturan layer aktif. Hasil analisis akan diperjelas dengan menampilkan keterangan wilayah dan keterangan jumlah penduduk serta jumlah buta aksara di wilayah yang di inginkan oleh pengguna. Tampilan popup keterangan wilayah dapat dilihat pada gambar berikut.

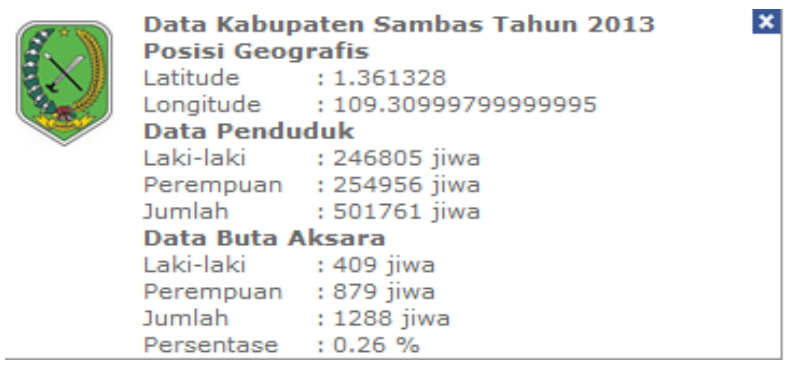

Gambar 9.Tampilan popup keterangan wilayah

Untuk masuk sebagai private user dan admin terlebih dahulu pengguna harus login dengan mengklik menu yang terdapat pada toolbar masuk. Tampilan halaman login dapat dilihat pada gambar berikut.

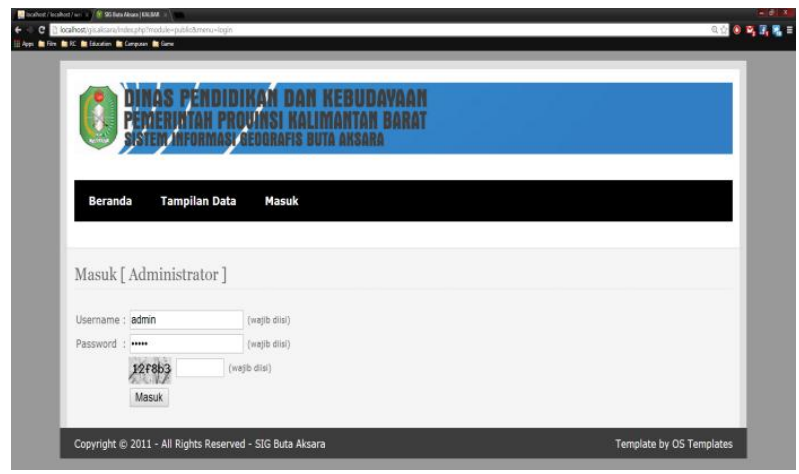

Gambar 10.Tampilan utama WebGIS buta aksara

\section{A. Tingkat Pengguna Public User}

Public user adalah pengguna umum yang terdiri dari masyarakat umum dan lembaga sosial masyarakat serta dinas-dinas terkait yang memerlukan data buta aksara. Public user adalah tingkat pengguna biasa yang hanya bisa melihat tampilan data buta aksara berdasarkan kabupaten, kecamatan dan kelurahan serta tahun. Untuk melihat data buta aksara baik rekapitulasi maupun data by name by address terlebih dahulu pengguna harus mengklik menu Tampilan Data yang terdapat pada toolbar. Tampilan data by name by address buta aksara dapat dilihat pada gambar ini. 


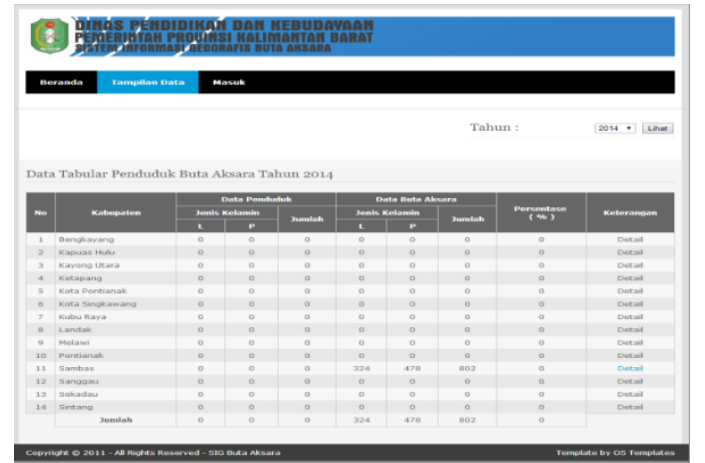

Gambar 11.Tampilan data by name by address buta aksara

Dari tampilan data di atas dapat dilihat rekap buta aksara masing-masing kabupaten. Jika kabupaten tersebut telah menginputkan datanya kedalam database maka pengguna akan dapat melihat detail data buta aksara berdasarkan by name by address sesuai kabupaten yang dipilih. Untuk tampilan data tabular data buta aksara dapat dilihat pada gambar berikut.

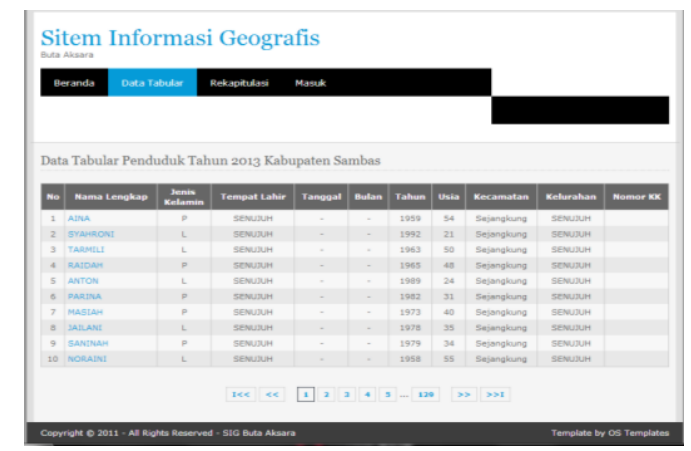

Gambar 12.Tampilan data buta aksara kecamatan sejangkung

Dari data tersebut pengguna dapat melihat lebih rinci lagi data by name by addres buta aksara yang menampilkan foto dari tiap record. Hanya dengan mengklik data yang diinginkan pada tabel grid maka panel data detail buta aksara akan muncul. Panel detail buta aksara dapat dilihat pada gambar berikut.

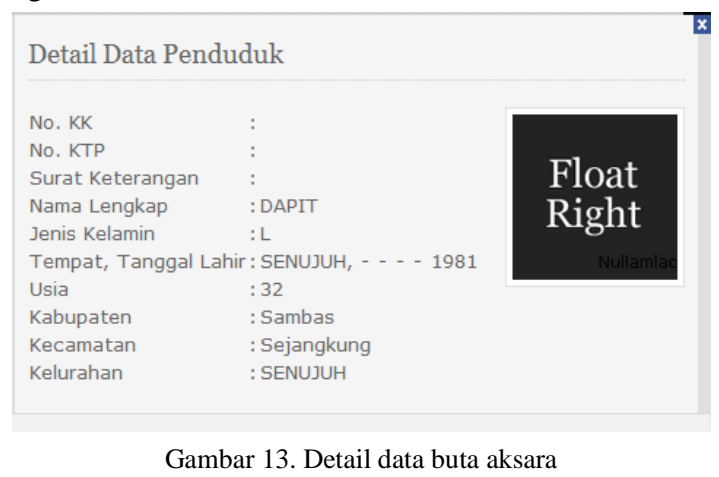

Selain data by name by addres, pengguna biasa juga bisa melihat hasil rekapitulasi data buta aksara berdasarkan kabupaten, kecamatan, kelurahan, usia dan jenis kelamin. Tampilan utama halaman rekapitulasi data dapat dilihat pada gambar berikut.

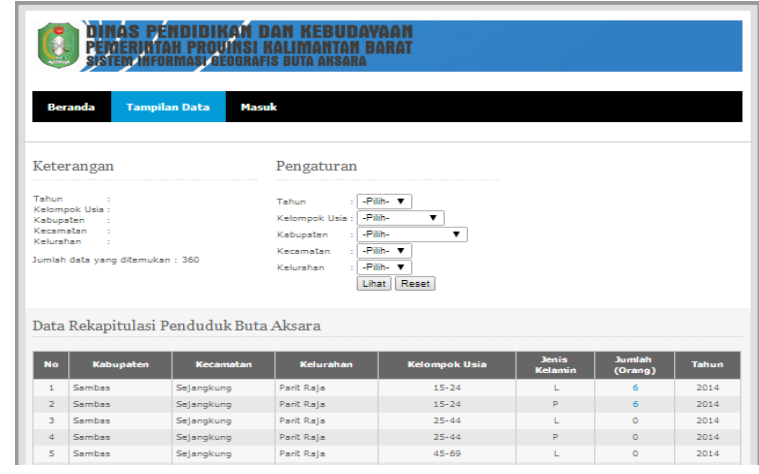

Gambar 14.Tampilan utama halaman rekapitulasi data

\section{B. Tingkat Pengguna Private User}

Private user adalah tinggat pengguna yang berada di kabupaten di Provinsi Kalimantan Barat. Untuk masuk kehalaman ini pengguna di tingkat kabupaten harus login terlebih dahulu. Pada dasarnya, beberapa fungsi yang terdapat pada private user sama dengan yang ada pada pengguna biasa, hanya saja pada private user ada beberapa hak akses yang tidak dimiliki oleh pengguna biasa yaitu memanajemen data buta aksara dan manajemen data pribadi pengguna. Tampilan utama halaman private user dapat dilihat pada gambar berikut.

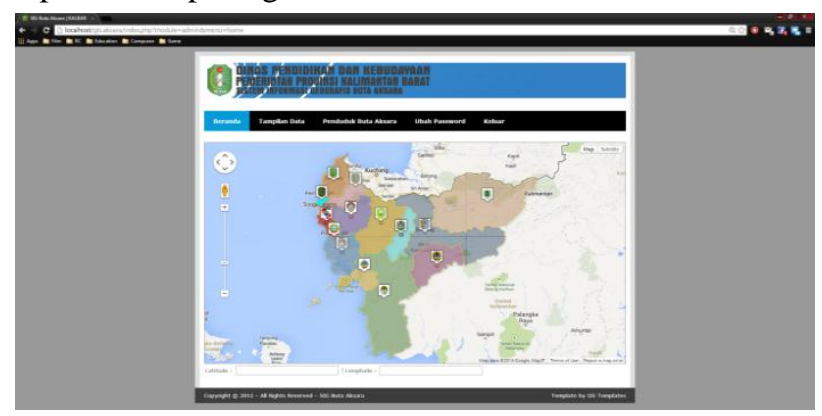

Gambar 15.Tampilan utama halaman private user

Untuk memanajemen data buta aksara yang ada di kabupaten pengguna harus masuk kehalaman manajemen data dengan mengklik menu penduduk buta aksara yang terdapat pada toolbar menu. Tampilan utama halaman manajemen data buta aksara dapat dilihat pada gambar berikut.

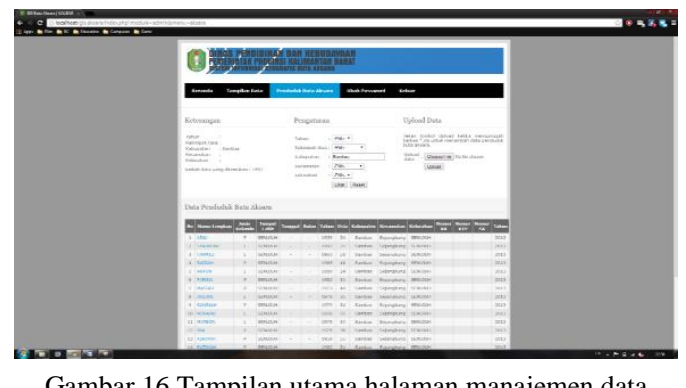

Untuk mengupload file data buta aksara by name by addres yang baru terlebih dahulu pengguna harus memilih file inputan data buta aksara kabupaten dengan format*.xls(Microsoft Excel), kemudian tekan button upload. Setelah itu data hasil upload dapat dilihat dengan memilih pengaturan tampilan data yang terdapat pada 
bagian atas halaman manajemen data. Sebagai contoh peneliti akan melihat data Kabupaten Sambas Kecamatan Sejangkung Desa Parit Raja yang telah berhasil di upload.

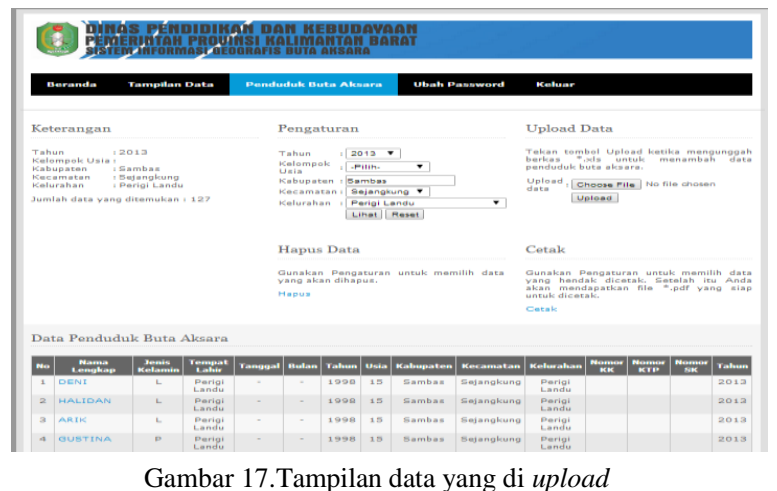

Selain mengupload data, pengguna juga bias menghapus data berdasarkan kabupaten, kecamatan, kelurahan dan tahun data dengan mengklik button hapus yang terdapat pada bagian atas tabel buta aksara. Jika ingin mencetak data yang telah di upload pengguna harus mengklik button cetak yang terdapat pada bagian atas tabel buta aksara. File buta aksara yang akan dicetak berupa format *.pdf yang di unduh melalui browser. Tampilan data buta aksara yang di unduh dapat dilihat pada gambar berikut.

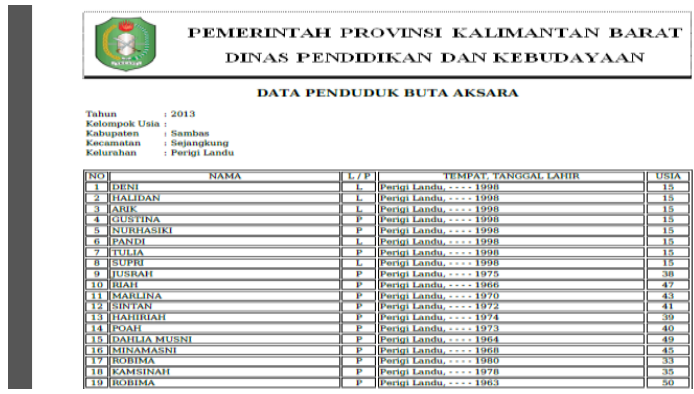

Gambar 18.Tampilan data buta aksara yang akan dicetak

Untuk memanajemen password pengguna harus mengklik ubah password yang terdapat pada toolbar menu. Tampilan ubah password dapat dilihat pada gambar berikut.

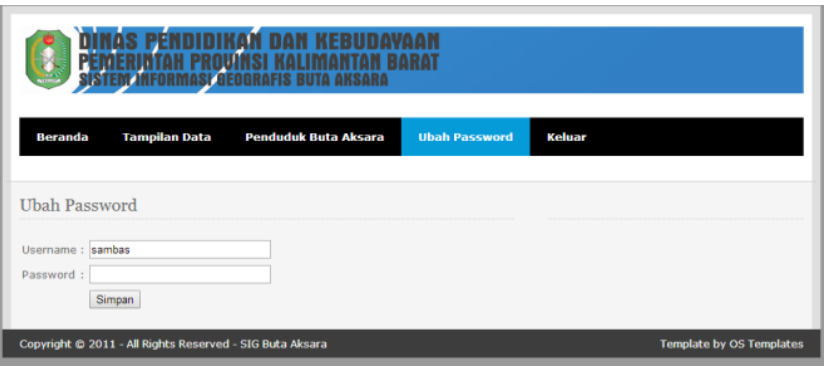

Gambar 19. Tampilan halaman utama manajemen ubah password

\section{Tingkat Pengguna Operator}

Operator merupakan tingkat pengguna yang paling tinggi dari system aplikasi WebGIS Pemetaan Buta Aksara ini. Operator adalah pengguna yang berada di Dinas Pendidikan dan Kebudayaan Provinsi Kalimantan Barat. Operator bertugas memantau dan mengkoordinir keseluruhan dari sistem aplikasi WebGIS ini. Operator dapat melakukan semua apa yang di akses oleh pengguna biasa dan private user. Ada beberapa perbedaan hak akses dari kedua tingkat pengguna diatas yang hanya bisa dilakukan oleh operator diantaranya menentukan private user, rekap data buta aksara dan manajemen data buta aksara kelompok masyarakat khusus. Tampilan utama halaman Operator dapat dilihat pada gambarberikut.

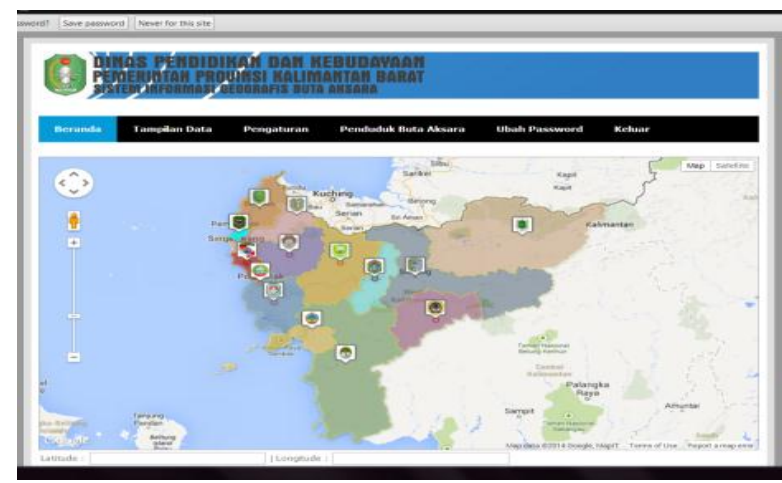

Gambar 20.Tampilan utama halaman operator

Untuk menentukan pengguna pada masing-masing kabupaten yang berhak login keaplikasi WebGIS ini terlebih dahulu operator harus mengklik pengaturan yang terdapat pada toolbar menu, kemudian pilih menu operator. Setelah itu operator akan masuk kehalaman utama manajemen private user. Tampilan halaman utama manajemen private user dapat dilihat pada gambar berikut.

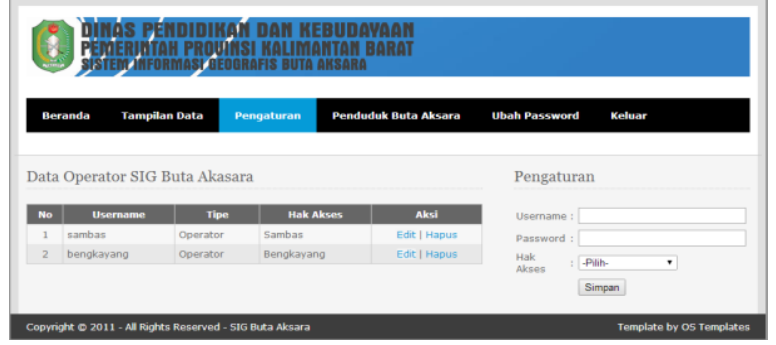

Gambar 21.Tampilan utama halaman manajemen data private user

Selain memanajemen data hak akses pengguna yang bisa login keaplikasi, operator juga dapat melakukan rekapitulasi data dengan mengklik sub menu rekapitulasi data yang terdapat pada menu.

Rekapitulasi data dilakukan agar pengguna data lebih mudah memahami dan membaca data tanpa harus menghitung satu persatu data buta aksara. Rekapitulasi data buta aksara didasarkan pengelompokan kabupaten, kecamatan, desa, usia, jenis kelamin dan tahun data. Untuk merekap data buta aksara, pengguna terlebih dahulu harus memilih data yang akan direkap dengan memilih beberapa opsi yang terdapat pada combobox yang telah disediakan. Jika telah memilih data yang akan direkap kemudian klik button rekap yang telah disediakan. Selain merekap data, operator juga bias mencetak hasil rekapitulasi data dengan mengklik button cetak. File data yang akan dicetak akan di unduh dalam format *.pdf. 


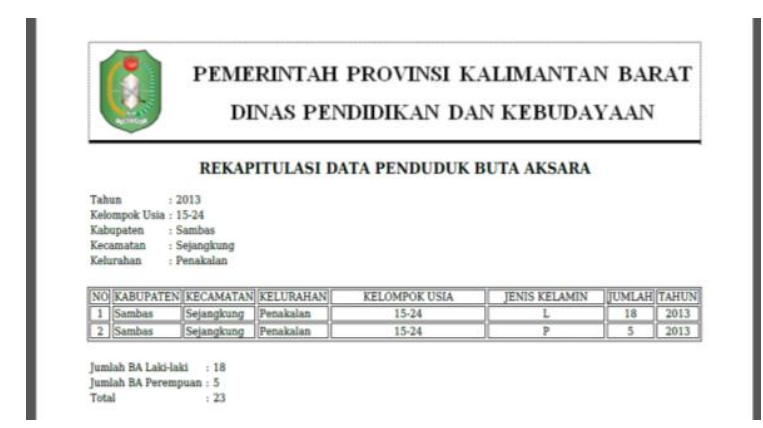

Gambar 22.Tampilan hasil cetak rekapitulasi data

Selain beberapa hal diatas, operator juga bisa mengatur pengelompokan buta aksara masyarakat khusus dan menambah kategori jenis kelompok masyarakat khusus. Untuk menambah kategori kelompok masyarakat khusus, operator harus masuk kehalaman "kategori daerah khusus" pada tab menu pengaturan. Halaman utama pengaturan kategori masyarakat khusus dapat dilihat pada gambar berikut.

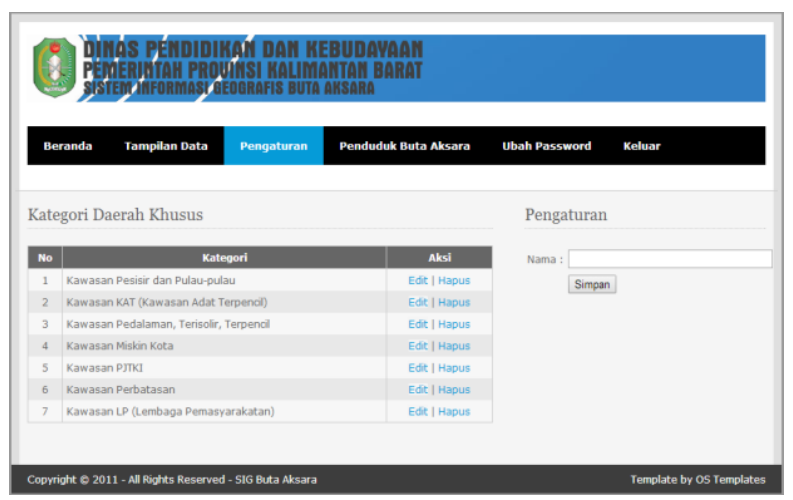

Gambar 23.Tampilan halaman pengaturan kategori daerah khusus

Sama halnya dengan manajemen data private user, pada halaman ini operator dapat memanipulasi data kategori pengelompokan masyarakat khusus. Setelah menentukan kategori masyarkat khusus, operator bisa menentukan langsung pengelompokan masyarakat khusus dengan masuk kehalaman pengelompokan daerah khusus. Tampilan utama pengelompokan daerah khusus dapat dilihat pada gambar 23 .

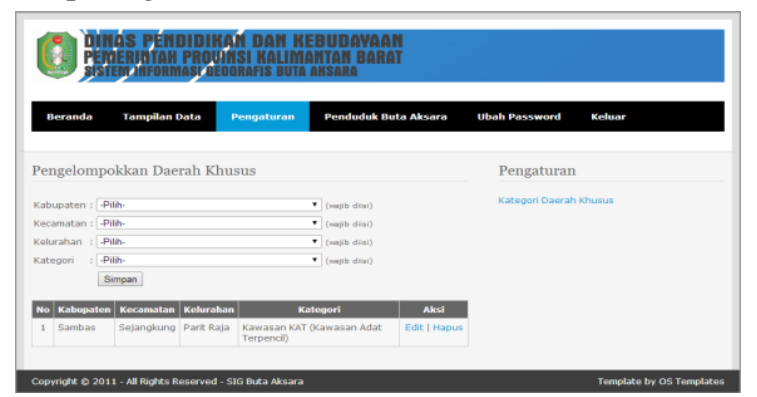

Gambar 24.Tampilan halaman pengaturan pengelompokan daerah khusus

\section{HASIL DAN ANALISIS}

Pengujian (testing) suatu kegiatan dilakukan untuk mewujudkan desain menjadi suatu web site. Teknologi yang digunakan tergantung dengan kebutuhan yang telah dirumuskan pada tahap analisis. Pengujian dilakukan setelah implementasi selesai dilaksanakan. Pengujian meliputi beberapa parameter yang akan menentukan standar aplikasi berbasis web yang telah dibuat. Tahap pengujian adalah suatu proses untuk menguji aplikasi berbasis web yang telah selesai dibuat. Hal ini bertujuan untuk menemukan kesalahan dan kemudian memperbaikinya. Pengembang suatu aplikasi berbasis web mendapat tantangan besar untuk melakukan pengujian karena karakter aplikasi ini yang beroperasi pada jaringan dengan berbagai macam pengguna, berbagai macam sistem operasi, perangkat keras, browser, protocol komunikasi, dan lain-lain.

Ada beberapa pendekatan yang digunakan untuk melakukan pengujian, yaitu :

1) Pengujian fungsional dan operasional (fungsional and operational testing): Bertujuan untuk menguji masukan dan keluaran dariaplikasi ini. Hasil keluaran aplikasi bergantung dari teknologi yang digunakan, baik itu bahasa pemrograman maupun bahasa skrip yang digunakan. Untuk menguji code HTML dan CSS yang digunakan dapat menggunakan alat bantu W3C HTML Validation Service di http://validator.w3.org/ dan W3C CSS Validation Service di http://jigsaw.w3.org/cssvalidator/.

2) Pengujian navigasi (navigation testing): Hal ini digunakan untuk melihat kesesuaian antara desain navigasi dengan navigasi yang ada di aplikasi. Navigasi berhubungan dengan link-link yang terdapat didalam aplikasi. Untuk menguji link dapat digunakan alat bantu W3C Link Checker Service di http://validator.w3.org/checklink

3) Pengujian konfigurasi (configuration testing): Pengujian ini dilakukan pada sistemoperasi, browser, system perangkat keras dan perangkat lunak pendukung. Pengujian ini dilakukan untuk menentukan batas toleransi kebutuhan aplikasi akan perangkat lunak dan perangkat keras pendukungnya. AplikasiWebGIS ini compatible dengan berbagai jenis browser dengan system operasi windows $X P$, windows Vista, windows 7, windows 8, dan macbook serta aplikasi ini dapat diakses dengan smart phone baik android maupun IOS. Beberapa contoh uji coba dengan berbagai jenis browser.

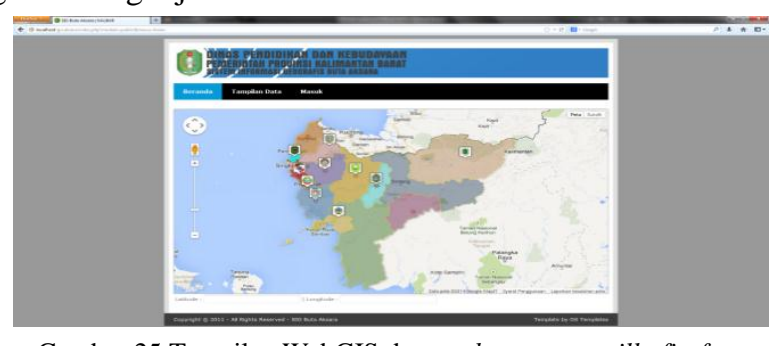

Gambar 25.Tampilan WebGIS dengan browser mozilla firefox 


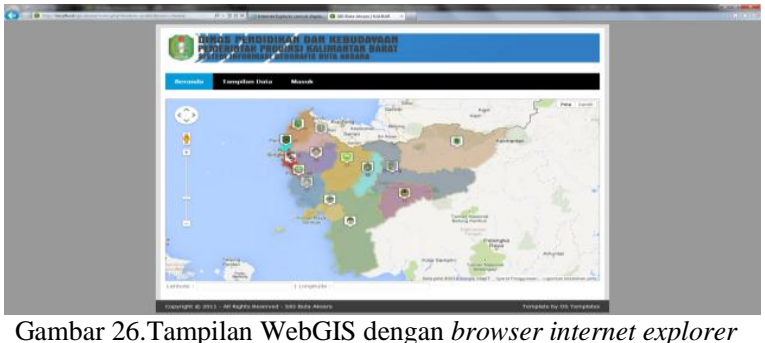

4) Pengujian keamanan dan performansi (security and performance testing): Pengujian ini dilakukan untuk melihat tingkat keamanan aplikasi dengan cara menguji aspek-aspek yang dapat menimbulkan gangguan keamanan aplikasi maupun server. Keamanan aplikasi sangat bergantung pada teknologi pengembangan website, konfigurasi server yang digunakan dan kelakuan sistem. Pengujian performansi dapat dilakukan bersamaan dengan pengujian keamanan aplikasi, karena keamanan aplikasi berbasis web juga tergantung dari performansi server dan aplikasi tersebut. Beberapa kriteria pengujian keamanan suatu web adalah Kerahasiaan, Otorisasi, Otentifikasi, Akuntabilitas dan Integritas

\section{A. Karakteristik Kualitas}

Pengguna mengharapkan fungsi-fungsi tertentu tersedia 24 jam per hari dan 7 hari seminggu $(24 \times 7)$, mudah digunakan, handal, cepat, kompatibel dengan sistem lain dan sejenisnya. Taksonomi umum untuk karakteristik kualitas produk perangkat lunak ditentukan dalam ISO / IEC9126-1 standar. Standar ini menyebutkan enam kategori utama karakteristik, yaitu :

1) Fungsionalitas: Dari pengujian secara langsung, web ini memiliki fungsionalitas yang kompleks sesuai dengan apa yang telah dirancang pada perancangan sistem dan prototype sistem

2) Keandalan: Web ini di hosting dengan space kuota penyimpanan data sebesar 1 GB dengan bandwidth akses per bulan $100 \mathrm{~GB}$.

3) Kegunaan: Seperti yang telah dipaparkan di atas, bahwa web ini sangat berguna untuk menghimpun dan mengolah data buta aksara sehingga menjadi suatu informasi berupa peta (spasial) dan tabel (tabular) yang mudah di pahami.

4) Efisiensi: Dari segi efisiensi, berdasarkan pengujian UAT web ini dianggap efisien dalam segi penggunaan memory dikarenakan web ini dirancang dengan bahasa pemprogram terstruktur berbasis OOP (Object Oriented Programming) yang dapat meminimalisir penggunaan memory, sehingga akan lebih mudah dan cepat di akses.

5) Pemeliharaan: Untuk pemeliharaan web ini akan dilakukan maintenance bergulir dengan skala per tiga bulan untuk mengecek bug dan masalah internal sistem.

6) Portabilitas: Dengan adanya web ini, pengguna yang ingin mengetahui jumlah dan sebaran buta aksara tidak perlu lagi membawa data hardcopy, akan tetapi hanya tinggal mengakses alamat website dimana WebGIS buta aksara di hosting.

\section{B. Test Objektif}

a) Pengujian tidak akan dapat meningkatkan mutu kecuali kesalahan yang terdeteksi dan dihapus.

b) Tujuan Utama pengujian adalah untuk menemukan kesalahan, bukan untuk menunjukkan ketidakadaan masalah.

c) Tes perangkat lunak cocok untuk membuktikan adanya kesalahan.

d) Jika tes tidak menemukan kesalahan, maka ini tidak berarti bahwa diuji aplikasi tidak terdapat kesalahan. Hanya mungkin belum terdeteksi.

e) Bagian-bagian dimana kesalahan tidak terdeteksi, dan memiliki konsekuensi paling kritis, harus diuji terlebih dahulu.

f) Sebuah pengujian disebut berhasil jika kesalahan terdeteksi, dan informasi tambahan tentang masalah dan status aplikasi tersebut diperoleh.

g) Gagal tes, yakni, tes yang tidak menemukan kesalahan.

h) Pengujian pada umumnya, dan proyek-proyek web pada khususnya, harus dapat mendeteksi berbagai kesalahan sebanyak mungkin, dengan biaya serendah mungkin, dalam periode waktu yang singkat dan sedini mungkin.

\section{Level Test}

a) Unit test: uji unit terkecil (kelas, halaman Web, dan lain-lain). Unit testing dilakukan oleh pengembang selama implementasi.

b) Integrasi tes: mengevaluasi interaksi antara unit yang berbeda dan terpisah. Integrasi tes dilakukan oleh tester, pengembang, atau keduanya bersamasama.

c) Sistem tes: menguji sistem, lengkap terintegrasi. Sistem tes biasanya dilakukan oleh tim uji khusus.

d) Penerimaan tes: mengevaluasi sistem bekerjasama dengan atau di bawah naungan klien dalam suatu lingkungan yang paling dekat dengan lingkungan produksi.

e) Beta Tes: tes kerja yang ramah dengan versi awal produk dengan tujuan untuk memberikan umpan balik awal. Beta tes informal (tanpa rencana uji dan uji kasus) yang mengandalkan jumlah dan kreativitas pengguna potensial.

\section{Peran Tester}

a) Bertujuan untuk menemukan kesalahan dan memerlukan penguji atau tester yang memiliki sikap"destruktif" terhadap pengujian.

b) kualitas selalu merupakan masalah tim

c) pemisahan yang ketat terhadap pengujian dan pengembangan tidak disarankan dan memiliki risiko yang tinggi untuk menghambat kerjasama antara pengembang dan penguji. 
d) Tim proyek web biasanya multidisiplin, dan kerjasama tim biasanya berdurasi pendek, sulit bagi anggota tim untuk membangun kepercayaan yang dibutuhkan untuk menutup kolaborasi antara pengembang dan penguji.

\section{E. Spesifikasi Test pada Web Engineering}

a) Kesalahan dalam isi biasanya sering ditemukan dengan biaya mahal.

b) Broken link merupakan kesalahan yang sering terjadi misalnya, bila sebuah halaman web eksternal direferensikan.

c) Jumlah potensi perangkat besar dan karakteristik yang berbeda (Multi-platform)

d) Sulit mengenali budaya masyarakat misalnya bahasa. Membaca pesan dalam budaya yang berbeda (misalnya, Arab, Cina).

e) Kurangnya pengetahuan, missal dalam hal metodenya

f) Aplikasi Web terdiri dari sejumlah komponen software yang berbeda (misalnya, server Web, database, middleware) yang sering disediakan oleh vendor yang berbeda, dan dilaksanakan dengan teknologi yang berbeda.

g) "ketidakmatangan" metode ujian dan kurang memadainya alat yang digunakan.

h) Terjadinya perubahan, sehingga membuat software harus beradaptasi dan terjadi perombakan.

\section{F. Test Pendekatan}

1. Pendekatan Konvensional

a) Perencanaan: Langkah perencanaan mendefinisikan tujuan kualitas, strategi pengujian umum, hasil uji rencana untuk semua tingkat pengujian, metrik dan metode pengukuran, dan lingkungan pengujian.

b) Menyiapkan: Langkah ini melibatkan teknik pengujian dan alat untuk menetapkan Uji kasus (termasuk data pengujian).

c) Melakukan: Langkah ini menyiapkan infrastruktur tes, menjalankan uji kasus, dan kemudian dokumen dan mengevaluasi hasilnya.

d) Pelaporan: Langkah terakhir ini merangkum hasil tes dan menghasilkan laporan uji.

2. Pendekatan Agile

a) Pendekatan Agile mengasumsikan bahwa tim akan mencari solusi untuk masalah-masalah bersama dan mandiri.

b) pengujian bukan masalah peran tetapi kerjasama yang erat dan penggunaan terbaik dari kemampuan yang tersedia di tim.

c) tester khusus pada tim yang mendukung para pengembang dan mengasumsikan jaminan kualitas kepemimpinan dalam tim.

\section{G. Analisis Sistem}

Analisis kegiatan untuk menentukan persyaratanpersyaratan teknik dan mengidentifikasi informasi yang akan ditampilkan pada aplikasi berbasis web. Analisis yang digunakan pada rekayasa web dilakukan dari empat sisi, yaitu:

1) Analisis Isi Informasi (Content): Mengidentifikasiisi yang akan ditampilkan pada aplikasi berbasis web ini. Isi informasi dapat berupa teks, grafik, audio, maupun video.

2) Analisis interaksi (Interaction): Analisis yang menunjukkan hubungan antara web dengan pengguna.

3) Analisis fungsional (function): Analisis tentang proses bagaimana aplikasi berbasis web ini akan menampilkan informasi kepada pengguna.

4) Analisis konfigurasi (Configuration): Konfigurasi yang digunakan pada aplikasi berbasis web, internet, intranet, atau extranet. Selain itu, analisis ini juga meliputi relasi database dengan web jika diperlukan.

\section{KESIMPULAN}

Setelah dilakukan penelitian, maka dapat disimpulkan bahwa :

1. Aplikasi WebGIS ini merupakan aplikasi yang menghimpun data buta aksara Provinsi Kalimantan Barat yang dapat di up date dengan menggunakan single server sehingga meminimalisir terjadinya kekeliruan akan data buta aksara antar lintas sektor

2. Aplikasi WebGIS ini merupakan media dan sarana penghubung antara kabupaten dan provinsi untuk data buta aksara. Dengan adanya WebGIS ini kesulitan akan menghimpun data buta aksara diharapkan dapat teratasi

3. Aplikasi WebGIS ini dibangun dengan suatu kesatuan sistem yang kompleks, dapat memberikan informasi yang mudah dipahami, cepat dan tepat mengenai data buta aksara diharapkan dapat membantu stakeholder terkait dalam mengambil keputusan untuk hal-hal yang berkenaan dengan buta aksara.

4. Aplikasi WebGIS ini dibangun dengan pemanfaatan google fusion table dan google maps api untuk menampilkan peta.

5. Aplikasi WebGIS ini compatible dengan segala macam browser dan support di akses pada smart phone.

Adapun rekomendasi yang dapat diberikan untuk mendukung optimalisasi dari penggunaan aplikasi WebGIS ini, yaitu:

1. Pemutakhiran data buta aksara yang harus dilakukan per enam bulan ataupun per tahun sehingga data buta aksara yang di tampilkan selalu up to date. Dengan adanya pemutakhiran data yang bergulir secara teratur maka akan memudahkan pihak-pihak terkait untuk melakukan upaya pemberantasan buta aksara.

2. Perlu dilakukan juga beberapa hal yang berkaitan dengan data-data teknis Diknas untuk aplikasiaplikasi lain berbasis WebGIS seperti sebaran sekolah dan sarana prasarana penunjang pendidikan serta 
pemrosesan data sarana pendidikan sekolah rawan pasca bencana alam di Kalimantan Barat.

\section{REFERENSI}

[1] Abdul Kadir, (2010), Mudah Mempelajari Database My SQL, Andi Offset, Yogyakarta.

[2] Charter, Denny, Desain dan Aplikasi GIS, PT. Elex Media Komputindo, Jakarta, 2004

[3] FitriImansyah, 2019, Pemetaan Sebaran Data Buta Aksara Dengan Sistem Informasi Geografis Dan Database Engine, (Jurnal Edukasi dan Penelitian Informatika) ISSN(e): 2548-9364 / ISSN(p) : 24600741

[4] Karim, Syaeful dan Djauharry Noor. 2006. Analisis Dan Perancangan Sistem Informasi Geografis Sebagai Alat Bantu Pembuat Keputusan Alokasi Industri Di Wilayah Kota Depok. Yogyakarta, Indonesia: Universitas Bina Nusantara.

[5] Kusrini. 2007. Konsep dan Aplikasi Sistem Pendukung Keputusan. Yogyakarta: Andi Offset.

[6] Muhajir, Ahmad, Syamsinar, dan Ilham Alimuddin. 2005. Aplikasi SIG Dalam Pembuatan Sistem Informasi Data Kota Makassar. Surabaya, Indonesia: Institut Teknologi Sepuluh November.

[7] Nuarsa IW. 2005. Belajar Sendiri Menganalisis Data Spasial Dengan Software GIS GIS 3.3 untuk Pemula . Jakarta : PT Alex Media Computindo.

[8] Prahasta, Eddy, (2002), Konsep-konsep Dasar Informasi Geografis, Informatika, Bandung.

[9] Rahman, Abdul, Spasial Data Modelling For 3D GIS, Springer, Berlin, 2008

[10] Soraya Rizky Puspitasari, Moehammad Awaluddin, Hana Sugiastu Firdaus, Pembuatan Aplikasi Webgis Untuk Informasi Persebaran Sarana Dan Fasilitas Kesehatan Di Kabupaten Kudus, Jurna Geodesi Undip Juli 2018. Volume 7, Nomor 3, Tahun 2018, (ISSN: 2337-845X)

[11] Tata Sutabri, (2004), Analisa Sistem Informasi, Andi Offset, Yogyakarta.

[12] Yousman, Yeyep. 2004. Sistem Informasi Geografis dengan ArcView3.3 Professional . Yogyakarta: Andi Offset. 